Gruenbichler, R., Klucka, J., Haviernikova, K., \& Strelcova, S. (2021). Business Performance Management in Small and Medium-Sized Enterprises in the Slovak Republic: An Integrated ThreePhase-Framework for Implementation. Journal of Competitiveness, 13(1), 42-58. https://doi.org/10.7441/ joc. 2021.01 .03

\title{
Business Performance Management in Small and Medium-Sized Enterprises in the Slovak Republic: An Integrated Three-Phase-Framework for Implementation
}

\section{- Rudolf Gruenbichler, Jozef Klucka, Katarina Haviernikova, Stanislava Strelcova}

\begin{abstract}
Business performance management (BPM) is an instrument that allows the fulfillment of business objectives and the improvement of competitiveness in small and medium-sized enterprises (SMEs). When BPM is implemented and measured, it can improve the sustainability and competitiveness of the enterprise. Despite its potential benefits, the possibilities of BPM in SMEs are often underestimated due to the lack of resources (mainly personal or financial). The goal of this paper is to introduce a framework for the implementation of BPM in Slovak SMEs based on research on transportation SMEs. To this end, certain steps that support the efficient introduction and use of BPM in these SMEs will be proposed. Our proposal regarding the performance of BPM is based on the findings of previous research studies along with the results of own questionnaire surveys and personal meetings/interviews with owners/managers of transportation SMEs. The results of this research shows that SMEs are generally not familiar with BPM and how the system is used. Essential elements to implement BPM are lacking in SMEs, and although the BPM system might help these firms improve their competitiveness, SMEs remain uniformed about the advantages of BPM. The proposed framework of BPM implementation in this paper can be used to inform SMEs and to assist them in their decisionmaking processes regarding the application of this system.
\end{abstract}

Keywords: business performance management, competitiveness, implementation, framework, indicators, digitalization, information system

JEL Classification: M21, L25, C12

Received: February, 2020

1st Revision: September, 2020

Accepted: January, 2021

\section{INTRODUCTION}

For SMEs competitiveness is a complex challenge which encompasses multiple areas. One option of how to improve competitiveness is the use of the processes of business performance management (BPM). When SMEs attempt to institute BPM, however, it is particularly during 
the implementation phase that a great deal of confusion can be found and numerous mistakes can be made.

The connection between BPM and competitiveness in SMEs has been confirmed by numerous authors such as Bianchi et al. (2015), Haseeb et al. (2019), and Pejić Bach et al. (2019). Each SME should have clearly stated business objectives, the fulfillment of which should be carefully monitored, as the terms by which these goals can be fulfilled provides essential information for the owners/top management and investors. Studies by Glaister et al. (2008), Hernaus et al. (2011), Pekkola et al. (2016), Tuček (2015), and others have confirmed the relationship between strategic planning and business performance. In this regard, the process of BPM can be seen to consist of various issues: the identification of performance measures (Bianchi et al., 2015), implementation of measures into managerial decisions (Bititci et al., 2011), collection of data (Campos et al., 2017), availability of qualified staff (Whitford \& Coetsee, 2006), and readiness of owners/managers to communicate results within an enterprise. These as well as other issues are necessary for the successful implementation of BPM (Frolick \& Ariyachandra, 2006). As BPM implementation seems better suited for the development for large companies, the literature presents only limited research in the context of SMEs (Pekkola et al., 2016), while no studies focusing on a specific area of SME business have been published at all. Based on research in Slovak and Austrian SMEs within the research project "Business Performance Management in SMEs in the Slovak Republic and Austria," No. SK-AT-2017-0003 it was identified that it was during the implementation phase that many BPM projects failed. Thus the research study presented in this paper sought to provide a tool that might help entrepreneurs in SMEs with the process of BPM implementation.

This paper aims to prepare the proposal of a model for BPM implementation and the use of BPM in Slovak SMEs based on the example of transportation SMEs. We focus on two main aspects: (1) the approach of Slovak SMEs to BPM implementation, and (2) the BPM implementation process, which covers problems that might be mitigated. We distinguish between BPM and performance measurement, with the first expression articulating the complexity of the topic and the second mirroring objectives related to key performance indicators (KPIs) in terms of defining them and describing their relevance for the managerial process within BPM implementation. Hence, this paper emphasizes the necessity for a new framework for a model to provide direction to SMEs in measuring and managing their performance with the ultimate goal of increasing their competitiveness through the BPM implementation.

This paper is structured as follows: Section 2 briefly provides an overview of international studies dealing with research in BPM implementation and the use of BPM in SMEs. These main findings - including problematic issues - were used to create the analytical framework and determine the research questions and hypotheses. Section 3 consists of an explanation of research procedures we deemed necessary to achieve our main objective. Section 4 presents the results of our research. Finally, the summarization of the main findings and our proposal for a model framework for BPM implementation in SMEs is proposed in Section 5. 


\section{THEORETICAL BACKGROUND AND HYPOTHESES DEVELOPMENT}

The steps required to improve SME performance based on competitive strategies has been a prominent topic of research since the mid-1990s, with many frameworks and approaches developed and discussed in this respect. Performance management (PM) represents a useful framework to drive decision-makers in SMEs towards designated competitive strategies and the measurement of the resultant outcomes (Bianchi et al., 2015). The key necessity for the market success of SMEs is the improvement of their business processes through quality implementation (Seotlela \& Mirkua, 2014) in terms of the use of BPM.

In the literature various definitions of BPM can be found, including the definition of BPM as the category of systems which can originate from purposes and objectives (Ferreira \& Otley, 2009; Whitford \& Coetsee, 2006), and BPM as the iterative closed-loop process aimed to manage and improve individual and corporate performance through continuous adaptation to the changing operating environment (Ates et al., 2013). Pejić Bach et al. (2019) consider BPM as a holistic management approach allowing organizations to realize performance and monitoring processes and to facilitate process improvements toward positive organizational performances. Okręglicka et al. (2015) define BPM as a comprehensive approach to realizing efficient and effective business processes within an economic entity. The value of BPM in companies (including SMEs) is recognized as a way for them to achieve strategic alignments and to succeed in the effective creation and implementation of a business strategy (Ariyachandra \& Frolick, 2008). Although BPM has been shown to allow SMEs to keep up with changes in the business environment, the BPM agenda is underestimated within SMEs, with little attention devoted to this issue (mainly due to a lack of personnel capacity or financial resources). Nevertheless, a company can enhance performance outcomes with BPM, e.g. by making sure employees are in the right job (Korauš et al., 2020).

BPM starts from objectives, which represent the main components that help formulate initiatives in planning, progress, reward, and improvement. Without clear goals, the time and energy spent on various activities often contribute very little to the organization's success (Stefan et al., 2010). For the strategic objective to be achieved, organizations must focus on critical success factors and ensure that planning, budgeting, forecasting, and reporting are aligned with their objectives. Under these conditions, BPM solutions can be proactive in helping organizations improve their ongoing business operations and processes (Frolick \& Ariyachandra, 2006).

Based on definitions in other papers dealing with definitions of BPM, the following statements can be made in summary:

- There is a difference as well as a relation between performance measurement and performance management; measurement consists of tools that allow measuring processes, and these measures can be applied in specific management activities within an enterprise; measurement is the subset of management.

- BPM focuses on the achievement of business objectives.

- To achieve positive business results, it is obligatory to perform key processes with reasonable outcomes. 
- BPM implementation and its regular use can be applied within an enterprise by the project management approach; as more than $80 \%$ of these projects have been shown to fail, implementation must be carefully planned and a clear and specific framework to allocate resources implemented.

BPM implementation is a comprehensive problem. Previous research studies (Assarlind et al., 2013) have shown that a reasonable number of companies are not successful in BPM implementation and its regular use in their enterprises. According to Jamil \& Mohamed (2011), BPM models and frameworks are designed to support management through the measurement of their performance, i.e. analyzing and improving their performance through better decisionmaking, for which a certain amount of necessary information is required (Ključnikov et al., 2019). The business sector is directly linked to many indicators (Mura et al., 2018) and BPM implementation data. The implementation phase is targeted at various aspects that create the framework for the successful/unsuccessful application of BPM in day-to-day management in an enterprise. This complex array of factors involved include people, communications, responsibilities, data, sources, and top management attitude.

The system of performance measurement also plays a vital role in BPM. Especially in terms of relatively recent turbulent market changes, it has become even more necessary to investigate current performance measurement practices (Pekkola et al., 2016) in SMEs. Heinicke (2018) has emphasized that performance measurement systems might be affected by SME specificity, which can be defined in terms of company size or resource limitations. The measurement of a particular SME's performance plays a vital role in maximizing its business efficiency (Dobrovic et al., 2018). This is done by using an effective performance measurement system with meaningful metrics, i.e. so-called Key Performance Indicators (KPIs). The identification of these indicators involved a complex multi-criteria decision-making process (Pavelková et al., 2018). Authors such as Davenport et al. (2010) and Rajnoha et al. (2015) have defined KPIs as measures that quantify an enterprise's overall performance in connection to its global objective or critical success factors.

The issues of BPM in SMEs can be related to many small-scale problems which have been observed in various literature sources from several, although limited, perspectives (Ates et al., 2013; Davenport et al., 2010; Bianchi et al., 2015; and many others). Therefore, this paper aims to offer the recommendation and key activities that should be linked in a useful and actionable framework to implement and practice BPM based on the example of transportation SMEs. To provide SMEs with recommendations for improving their competitiveness, it is necessary to explain the system of implementation of BPM for them. It is needed to investigate their current practice in performance management and, based on these results, contribute to the research gap related to BPMe implementation in SMEs. From the stated above, the research questions follow. Q1. What is the current situation in Slovak transportation SMEs regarding BPM implementation? Q2. What is the connection between the strategic plan and implementation of BPM in Slovak transportation SMEs? Q3. Which indicators are essential for the measurement of SMEs' performance?

To accomplish the answers to the stated questions, we proposed hypotheses in the next part of the paper. An organization's business performance is affected by factors from its outside and internal resources (Belas et al., 2019). Moreover, the BPM implementation is affected by many 
factors. It is possible to categorize them into three main groups: organizational, technical, and methodology related. The most critical are organizational factors determined by a corporate culture that facilitate an effective BPM implementation (Frolick \& Ariyachandra, 2006) because BPM helps SMEs build competitive advantage by using the potential of their human capital (Whitford \& Coetsee, 2006). The organizational structure, together with the size of the company, management style, information system (Kordos \& Ivanova, 2017), and system maturity, according to Bititci et al. (2011), belong to crucial factors that affect the success or failure of performance measurement and competitiveness (Buganova \& Simickova, 2019). Previous studies showed that models of implementation of BPM are applied in general, without focusing on the company size (Ates et al., 2013; Pekkola et al., 2016), and as Çera et al. (2019) stated, in approach to boost entrepreneurship is not possible to use rule: "one size fits all". Therefore, our research takes into account the size category of a transportation SME.

H1: There is a relationship between the size category of SMEs and the implementation of BPM.

The literature sources have also identified many obstacles, which SMEs are facing within the implementation of BPM. One of them is strategic planning, which is in SMEs at a low level (Pekkola et al., 2016) despite being seen as a useful management tool for larger SMEs (Glaister et al., 2008; Hernaus et al., 2011). In our research, we hypothesize a relationship between the strategic plan and BPM use among Slovak transportation SMEs within analyzing the second hypothesis. H2: There is a relationship between SMEs with a strategic plan and the implementation of BPM.

Subsequently, the hypothesis is tested whether there is a relationship between transportation SMEs with strategic planning and BPM and their size category.

H3: There is a relationship between the size category of SMEs with strategic planning and BPM implementation.

\section{RESEARCH OBJECTIVE, METHODOLOGY AND DATA}

This paper aimed to prepare a proposal of the framework of a model for implementing the BPM system in the Slovak transportation SMEs. The proposed framework of the model is developed based on the knowledge of previous research studies of the authors Bianchi et al. (2015), Bititci et al. (2011), Campos et al. (2017), Rajnoha et al. (2015), Taticchi et al. (2010), Weber et al. (2017) and it is supported by results of own research done within the frame of the research projects. Its main features will be possible to implement in the BPM of SMEs from other sectors.

The research was executed in two phases through questionnaire surveys among Slovak SMEs. The first phase related to the identification of some specific items of BPM through the performed questionnaire surveys (during 2017-2018), which results were published in the previous authors' works (Klučka \& Kelíšek (2018), Strelcová \& Janasová (2018)).

The second phase was oriented towards issues related to the implementation of BPM in transportation SMEs - the identification of main problems and relations to other factors. Within this phase in 2019, authors had personal meetings and questionnaire surveys with SMEs' representatives (owners/managers). The questionnaire was designed to identify motivation, obstacles/constraints, and SMEs' approaches in BPM implementation and regular use. 
For this research, the transportation SMEs were selected using a random selection method from the Register of Financial Statements. There are 5.772 transportation SMEs in this register. We calculated the minimal valid sample size necessary for this research within a priory analysis executed in the chi-square tests' G* power software. The sample of 123 SMEs was calculated, when the power $(1-\beta$ err prob $)=0.80$, effect size $\mathrm{w}=0.28$, and $\alpha$ err prob $=0.05$. This implies an $80 \%$ chance of correctly rejecting the hypothesis of no difference between expected and observed proportions with 123 participants. We randomly selected more samples of SMEs (400) from the register than the minimal valid samples were calculated. Excluding one, which belonged to large SMEs, 169 SMEs completed the questionnaire with a response rate of 2.93\% from the total research sample. Within the questionnaire survey, the owners/managers of SMEs were asked to answer the BPM implementation questions in their company. We collected $79.29 \%$ of questionnaires from owners and $20.71 \%$ from managers in SMEs.

The questionnaire consisted of two main parts. In the first part, the main characteristics of SMEs were required. When integrating enterprises into categories (micro, small and medium), the authors used the European Commission's 2015 recommendations, according to which the number of employees (SMEs employing less than 250 persons - micro: 0-9, small: 10-49, medium: 50-249) is the primary criterion and the other two criteria, annual turnover, and yearly balance sheet, are merely additional criteria. According to the size category of SME, $53.25 \%$ of enterprises belonged to micro-enterprises, $34.32 \%$ to small enterprises, and $12.43 \%$ to mediumsized enterprises. These enterprises carried out their activities within eight self-governing regions in Slovakia (Bratislava 13.02\%; Trnava 11.83\%, Trenčín 12.43\%, Žilina 13.02\%, Nitra 11.83\%, Banská Bystrica 13.02\%, Prešov 11.83\%, and Košice 13.02\%).

In the second part of the survey, business performance questions related to stated hypotheses (Theoretical background and hypotheses development) were observed. The respondents were interviewed whether they perform enterprise performance management and if they have implemented the strategic plan. The system of BPM had been implemented by $25.44 \%$ of SMEs, and the strategic plan by $57.99 \%$ of respondents. $23.7 \%$ of respondents had implemented the system of BPM as well as the strategic plan. We also focused on reasons important for implementing BPM in transportation SMEs and indicators used for performance measurement.

After studying the data related to BPM implementation in transportation SMEs, the statistical verification of the stated hypotheses was performed. The hypotheses were based on the assumption that the implemented BPM system has more positive effects on SME's competitiveness. The hypotheses were tested at the level of significance $\alpha=0.05$, by using the Chi-square Test of Independence. The relationship between variables was evaluated through the value of Cramer's $\mathrm{V}(\mathrm{V})$.

The calculations were provided within statistical software $G^{*}$ Power 3.1 and STATISTICA 6.0.

\section{RESULTS AND DISCUSSION}

Table 1 reflects the results of SMEs' answers analyzing the hypothesis H1. From 169 responses to this question, $74.56 \%$ of respondents still have not implemented the system of BPM. In the case of an enterprise's size category, the highest number of SMEs (44.97\%), which still have not 
implemented the system of BPM, belonged to microenterprises. The implementation of BPM requires access to resources: financial, material, human, know-how, and others, especially in larger companies. The smallest companies have a higher probability that they will not implement BPM. The Chi-square test $(\mathrm{p}=0.003)$ shows a significant moderate (Cramer's V is 0.263 ) relationship between the size category of an SME and BPM implementation. We can confirm the H1.

Tab. 1 - Classification of SMEs in terms of their size and use of BPM. Source: own research

\begin{tabular}{|l|l|l|l|l|l|l|}
\hline \multirow{2}{*}{ Size category } & \multicolumn{6}{l}{ Have you implemented the BPM in the organization? } \\
\cline { 2 - 8 } & yes & $\%$ & no & $\%$ & total & $\%$ \\
\hline Micro & 14 & 8.28 & 76 & 44.97 & 90 & 53.25 \\
\hline Small & 19 & 11.24 & 39 & 23.08 & 58 & 34.32 \\
\hline Medium & 10 & 5.92 & 11 & 6.51 & 21 & 12.43 \\
\hline Total & 43 & 25.44 & 126 & 74.56 & 169 & 100.00 \\
\hline Chi-square test & $\mathrm{p}=0.003$ & 0.263 & \multicolumn{7}{|l|}{} \\
\hline Cramer's V & 0.003 & & \\
\hline
\end{tabular}

In setting the $\mathrm{H} 2$ hypothesis, the authors assumed that SMEs, which plan their long-term sustainability and competitiveness in strategic plans, would use the BPM system to control the achievement of business objectives. Table 2 depicts the results of our research. There were $57.99 \%$ of SMEs with the strategic plan, from which $23.67 \%$ also have implemented the system of BPM. The results of the $\mathrm{p}$-value $(\mathrm{p}=0.000)$ of the Chi-square test showed a significant relationship between the SMEs with the strategic plan and the implementation of BPM, and this relationship is relatively strong; the Cramer's V is 0.383 . We can conclude that $\mathrm{H} 2$ about the relationship between the SMEs with the strategic plan and BPM implementation was confirmed. This result is following the work of Glaister et al. (2008), Hernaus et al. (2011), Pekkola et al. (2016), Tuček (2015), and many others in which the relationship between strategic planning and firm performance was confirmed. These works confirmed the importance of strategic planning towards the implementation of BPM in SMEs. Our result suggests the importance of strategic alignment for SMEs, which was also confirmed by Haseeb et al. (2019) and Raffoni et al. (2018). They pointed out that if the company wants to survive, it is important to have defined the strategic objectives with goals, which should be possible to measure and manage. SMEs should realize that their organization's strategic alignment could boost sustainable competitive advantage and sustainable business performance with the implementation of BPM.

Tab. 2 - Classification of enterprises in terms of their size and use of BPM. Source: own research

\begin{tabular}{|l|l|l|l|l|l|l|}
\hline \multirow{2}{*}{$\begin{array}{l}\text { Have you implemented the system of } \\
\text { BPM in the company? }\end{array}$} & \multicolumn{6}{l}{$\begin{array}{l}\text { Have you implemented the strategic plan in the } \\
\text { company? }\end{array}$} \\
\cline { 2 - 8 } & yes & $\%$ & no & $\%$ & total & $\%$ \\
\hline Yes & 40 & 23.67 & 3 & 1.78 & 43 & 25.44 \\
\hline No & 58 & 34.32 & 68 & 40.24 & 126 & 74.56 \\
\hline
\end{tabular}




\begin{tabular}{|l|l|l|l|l|l|l|}
\hline Total & 98 & 57.99 & 71 & 42.01 & 169 & 100.00 \\
\hline Chi-square test & $\mathrm{p}=0.000$ \\
\hline Cramer's V & $\mathrm{p}=0.383$ \\
\hline
\end{tabular}

Table 3 provides an overview of the relationship between SME size category and the implementation of BPM in SMEs with a strategic plan (H3). Out of 98 SMEs with a strategic plan in our research, $40.82 \%$ have implemented the system of BPM. Out of this number, mainly the category of small enterprises (17.35\%) shows both factors in place. BPM is generally not important for microenterprises, with $31.63 \%$ of these SMEs not having a BPM system in place. Based on the Chi-square test $(\mathrm{p}=0.082)$, we can conclude that there is no significant relationship between the size of a SME with a strategic plan and BPM implementation. Thus Hypothesis H3 was not confirmed.

Tab. 3 - Classification of enterprises according to the relationship between the strategic plan and BPM system. Source: own research

\begin{tabular}{|l|l|l|l|l|l|l|}
\hline \multirow{2}{*}{ Size category } & \multicolumn{6}{l|}{ If you have the strategic plan, do you have BPM in place? } \\
\cline { 2 - 8 } & yes & $\%$ & no & $\%$ & Total & $\%$ \\
\hline Micro & 13 & 13.27 & 31 & 31.63 & 44 & 44.90 \\
\hline Small & 17 & 17.35 & 20 & 20.41 & 37 & 37.76 \\
\hline Medium & 10 & 10.20 & 7 & 7.14 & 17 & 17.34 \\
\hline Total & 40 & 40.82 & 58 & 59.18 & 98 & 100.00 \\
\hline Chi-square test & $\mathrm{p}=0.082$ & \multicolumn{7}{ll}{} \\
\hline
\end{tabular}

Based on the research of De Waal \& Counet (2009), we have adapted and adjusted 31 problem categories in terms of SMEs: 1) The implementation of BPM has low priority for managers/ owners in SMEs. 2) The implementation of BPM requires more time and tasks than expected. 3) The implementation of BPM involves the availability of resources and capacity, which are frequently insufficient. 4) The SMEs are in an unstable phase. 5) The implementation of BPM is without a clear goal. 6) Lack of management commitment. 7) The management of SMEs does not devote attention to the BPM implementation within the required period. 8) The positive attitude toward the implementation of BPM is lacking among the representatives of SMEs. 9) Insufficient commitment from middle management and staff for the BPM implementation and use. 10) The current ICT system does not support the BPM at the required level. 11) The representatives of SMEs do not adopt appropriate management styles. 12) A clear and understandable strategy in the SMEs is lacking. 13) It is difficult to define relevant CSFs. 14) There is not enough focus on internal management and control. 15) It is too challenging to decompose goals for the lower levels of the SME. 16) There is a lack of knowledge and skills regarding the BPM. 17) It is difficult to define relevant KPIs. 18) The KPIs are not linked to departmental, team, and individual responsibilities. 19) There are too many KPIs defined. 20) The SME measures the wrong KPIs. 21) The focus on BPM implementation results is in the foreground, while the change process of the SME is ignored. There is too much focus on the implementation results, while the change process of the SME is ignored. 22) There is resistance from SME representatives toward the new BPM. 23) There is an insufficient link between the BPM and the reward system. 24) The BPM 
lacks cause and effect relations or is over-complex due to too many causal relations. 25) The SME has no performance management culture. 26) The BPM is not used for the daily management of the organization. 27) The BPM is not regularly updated and maintained after implementation. 28) There is no representative in the SME appointed to take ownership of the BPM implementation and updates. 29) There are difficulties in getting the data to calculate the performance indicators. 30) The BPM receives a low priority, or its use is abandoned after a management change. 31) The benefit of the BPM implementation is not evident enough for SMEs.

We divided the afore-mentioned problems (1-31) into three main phases of BPM implementation. Each stage consists of selected and related issues (see Table 4).

Tab. 4 - Problems during implementation and recommendations for avoidance. Source: own research

\begin{tabular}{|c|c|c|c|c|c|c|}
\hline $\mathrm{Nr}$ & Phase & Pred.* & Anc.* & Activity & Probl. & Mitigation activities \\
\hline 1 & $\begin{array}{l}\text { Initiation \& } \\
\text { Planning }\end{array}$ & 0 & 2 & $\begin{array}{l}\text { sensitize } \\
\text { shareholders } \\
\text { and/or top } \\
\text { management to } \\
\text { the need for PM }\end{array}$ & $\begin{array}{l}\text { 1), 6), } \\
8), 9) \\
30)\end{array}$ & $\begin{array}{l}\text { communication within } \\
\text { internal and external } \\
\text { environments as a } \\
\text { source of knowledge }\end{array}$ \\
\hline 2 & Planning & 1 & 3 & $\begin{array}{l}\text { define and/or } \\
\text { visualize business } \\
\text { objectives and } \\
\text { strategies }\end{array}$ & $\begin{array}{l}4), \\
12), \\
15)\end{array}$ & $\begin{array}{l}\text { clarification of } \\
\text { approach and } \\
\text { identification of } \\
\text { internal and external } \\
\text { threats }\end{array}$ \\
\hline 3 & Planning & 2 & 4 & $\begin{array}{l}\text { identify required } \\
\text { knowledge for } \\
\text { PM (knowledge } \\
\text { management) }\end{array}$ & 16) & $\begin{array}{l}\text { education and training } \\
\text { to PM }\end{array}$ \\
\hline 4 & Planning & 3 & 5,12 & $\begin{array}{l}\text { allocate } \\
\text { resources for } \\
\text { implementation } \\
\text { (within budget) }\end{array}$ & $\begin{array}{l}\text { 2), 3), } \\
\text { 7) }\end{array}$ & $\begin{array}{l}\text { realistic planning and } \\
\text { budgeting for the } \\
\text { project }\end{array}$ \\
\hline 5 & Planning & 4 & 6,8 & $\begin{array}{l}\text { decide on a } \\
\text { suitable PM } \\
\text { system }\end{array}$ & (5) & $\begin{array}{l}\text { identification of a } \\
\text { responsible person/-s } \\
\text { and definition of } \\
\text { expected outcomes of } \\
\text { the project }\end{array}$ \\
\hline 6 & Planning & 5,14 & 7,13 & $\begin{array}{l}\text { define key } \\
\text { objectives in } \\
\text { consideration of } \\
\text { vision/objectives }\end{array}$ & 13) & $\begin{array}{l}\text { identification of } \\
\text { relevant KPI and } \\
\text { their communication/ } \\
\text { analysis within an } \\
\text { enterprise }\end{array}$ \\
\hline
\end{tabular}




\begin{tabular}{|c|c|c|c|c|c|c|}
\hline 7 & Planning & 6,13 & 8,13 & $\begin{array}{l}\text { define KPI for all } \\
\text { areas }\end{array}$ & $\begin{array}{l}17), \\
18), \\
19), \\
20)\end{array}$ & $\begin{array}{l}\text { identification of } \\
\text { relevant KPI and } \\
\text { their communication/ } \\
\text { analysis within an } \\
\text { enterprise }\end{array}$ \\
\hline 8 & $\begin{array}{l}\text { Planning, } \\
\text { Implementation }\end{array}$ & $\begin{array}{l}5,7 \\
13\end{array}$ & $\begin{array}{l}9,10, \\
11 \\
12\end{array}$ & $\begin{array}{l}\text { modify existing } \\
\text { management } \\
\text { system (processes } \\
\text { and org. } \\
\text { structure) and } \\
\text { incentive system }\end{array}$ & $\begin{array}{l}21), \\
25)\end{array}$ & $\begin{array}{l}\text { PM application in } \\
\text { internal norms, and } \\
\text { KPIs incorporation } \\
\text { into an incentive } \\
\text { system }\end{array}$ \\
\hline 9 & Implementation & 8 & 14 & $\begin{array}{l}\text { implement } \\
\text { measures and use } \\
\text { KPI }\end{array}$ & 26) & $\begin{array}{l}\text { identification of } \\
\text { responsibility and } \\
\text { database of KPI }\end{array}$ \\
\hline 10 & Implementation & 8,15 & 15 & $\begin{array}{l}\text { initiate change } \\
\text { process (change } \\
\text { management) }\end{array}$ & 14), 4) & $\begin{array}{l}\text { establishment of clear } \\
\text { relations and reporting } \\
\text { system within an } \\
\text { enterprise }\end{array}$ \\
\hline 11 & Implementation & 8,16 & 16 & $\begin{array}{l}\text { provide } \\
\text { employees with } \\
\text { information } \\
\text { (communication } \\
\text { management) }\end{array}$ & 10) & $\begin{array}{l}\text { improvement of } \\
\text { information flows } \\
\text { and their relations to } \\
\text { processes }\end{array}$ \\
\hline 12 & Implementation & $\begin{array}{l}4,8 \\
17\end{array}$ & $\begin{array}{l}9,11 \\
17\end{array}$ & $\begin{array}{l}\text { set up a } \\
\text { secondary org. } \\
\text { for project } \\
\text { implementation }\end{array}$ & 31) & $\begin{array}{l}\text { communication of } \\
\text { analysis within an } \\
\text { enterprise }\end{array}$ \\
\hline 13 & $\begin{array}{l}\text { Planning, } \\
\text { Implementation }\end{array}$ & $\begin{array}{l}6,7 \\
14\end{array}$ & 7,8 & $\begin{array}{l}\text { identify risks } \\
\text { for each activity } \\
\text { during the } \\
\text { implementation }\end{array}$ & 27) & $\begin{array}{l}\text { establishment of } \\
\text { formal procedures } \\
\text { with clear } \\
\text { responsibilities }\end{array}$ \\
\hline 14 & Reporting & 9 & 6,13 & $\begin{array}{l}\text { review objectives, } \\
\text { KPIs, and } \\
\text { measures }\end{array}$ & $\begin{array}{l}\text { 28), } \\
\text { 29) }\end{array}$ & $\begin{array}{l}\text { establishment of } \\
\text { formal procedures } \\
\text { with clear } \\
\text { responsibilities }\end{array}$ \\
\hline 15 & Reporting & 10 & 10 & $\begin{array}{l}\text { raise acceptance } \\
\text { among employees } \\
\text { and review } \\
\text { the change } \\
\text { management } \\
\text { process }\end{array}$ & $\begin{array}{l}\text { 22), } \\
\text { 23) }\end{array}$ & $\begin{array}{l}\text { communication and } \\
\text { analysis of costs and } \\
\text { benefits }\end{array}$ \\
\hline
\end{tabular}




\begin{tabular}{|l|l|l|l|l|l|l|}
\hline 16 & Reporting & 11 & 11 & $\begin{array}{l}\text { evaluate } \\
\text { communication } \\
\text { within the } \\
\text { company }\end{array}$ & & \\
\hline 17 & Reporting & 12 & 12,17 & $\begin{array}{l}\text { evaluate project } \\
\text { implementation }\end{array}$ & $30)$ & $\begin{array}{l}\text { communication and } \\
\text { analysis of costs and } \\
\text { benefits }\end{array}$ \\
\hline
\end{tabular}

*Pred -predecessor(s), Anc. - ancestor(s)

Based on the results of the statistical survey and the personal communication of the authors with owners/managers in SMEs, it can be stated that:

- Up to $42.01 \%$ of SMEs have no strategy plan, resulting in problems with the formulation of key enterprise processes. This also relates to the unclear objectives of the enterprise and issues with implementing the set goals.

- Finally, global/strategic thinking within departments is lacking. BPM is mainly focused on the measurement of non-financial performance parameters (Table 5) and the difficulties in delimitating what is to be evaluated concerning this issue.

Tab. 5 - Types of KPIs in transportation SMEs. Source: own research

\begin{tabular}{|l|l|l|l|l|l|l|l|l|}
\hline \multirow{2}{*}{$\begin{array}{l}\text { Size } \\
\text { category }\end{array}$} & \multicolumn{6}{|l|}{ Which indicators prevail in your system of performance measurement? } \\
\cline { 2 - 10 } & Financial & $\%$ & nonfinancial & $\%$ & $\begin{array}{l}\text { We don't } \\
\text { follow }\end{array}$ & $\%$ & Total & $\%$ \\
\hline Micro & 32 & 18.93 & 32 & 18.93 & 26 & 15.38 & 90 & 53.25 \\
\hline Small & 15 & 8.88 & 30 & 17.75 & 13 & 7.69 & 58 & 34.32 \\
\hline Medium & 4 & 2.37 & 16 & 9.47 & 1 & 0.59 & 21 & 12.43 \\
\hline Total & 51 & 30.18 & 78 & 46.15 & 40 & 23.67 & 169 & 100.00 \\
\hline
\end{tabular}

- The decision for the implementation of BPM is often associated with the purchase of specialized software and digitalization. Thus the measurement of business performance is limited.

- The next BPM implementation problem lies in the lack of qualified employees and in the poor selection process of the employees responsible for the BPM agenda. In most transportation SMEs $(76.33 \%)$, there is no such responsible employee. The worst situation concerns especially micro-enterprises, where this was the situation in up to $44.97 \%$ of cases. Thus the performance measurement is reduced to the selected employees, the information flow in the enterprise is not modified, and the competencies and tasks resulting from the performance measurement are not explicitly defined. This creates a pressure which is released through the denigration of the importance of the agenda; in enterprises with quality management, the business performance schedule is set and followed carefully.

Some of these findings are in line with other research studies. Pejić Bach et al. (2019) emphasized a positive correlation between the maturity level of BPM and the size category of SME. Bianchi 
et al. (2015) also focused on adapting performance management systems to SME characteristics, recommending a selective approach toward the employment of performance reporting tools. Kim \& Jeon (2016) confirmed the importance of improving competitive advantage and connected this to improving BPM. Okręglicka et al. (2015) pointed out that generally SMEs do not show a strong tendency to include BPM elements in their strategy of action. The results of other studies generally show that the BPM system is well elaborated for large companies, but its implementation in SMEs is complicated and only partially elaborated.

\section{CONCLUSION}

Based on the research results from the questionnaires, interviews and personal consultations with SMEs, answers to the research questions were identified encompassing the assumptions, experiences and practices of these entities in Slovakia. Regarding BPM implementation, one key result is that micro and small-sized companies (in the majority) indicated that they did not see the necessity to implement BPM. Various reasons were indicated for this perception: lack of knowhow and the associated lack of qualified and / or available personal. A positive trend, however, was indicated (Q1).

A company's strategic plan identifies its objectives, the feasibility and fulfillment of which BPM can measure in precise ways. Based on these goals and the evaluation of them by BPM, specific managerial activities can be applied, e.g. to avoid or mitigate negative consequences. We found that only companies which had implemented BPM were able to identify successes and failures in their current business practices to achieve effectiveness (Q2).

A variety of indicators can be introduced and used by SMEs for performance measurement. It is thought that three crucial issues related to this question are the sector in which the SME carries out its activities, the owner's personality in terms of his/her willingness to learn and communicate in the company, and the introduction of a software tool, which is often used for assessing the performance. The performance assessment should be based on an ad-hoc approach taken selectively, focusing on the profit/product, profit/customer, inventories, and the state of receivables and obligations. Fundamentals can be indicated, e.g. return on equity and return on assets. In SMEs in which an environment of communication is created, the results achieved as well as problems can be accurately assessed, following which measures to increase the company's competitiveness can be instituted (Q3).

The concepts and practices of performance management can support SMEs in regard to the setting of strategies and objectives as well as their fulfillment, and thus helping secure the company's success in the long-term. Systems have been developed for larger companies and used successfully in practice for many years; these systems should be adapted for the special conditions of SMEs. It is true that the introduction of BPM will continue to be one of the most significant challenges in companies. Still, the results of many studies indicate that companies want to rise to these challenges by introducing concepts and best practice solutions to implement a performance management system.

We here propose procedures regarding BPM implementation as a summary of identified problems in a three-phase-framework of a model (Figure 1) which explicitly considers the potential hurdles 
and problematics of the introduction and use of BPM. The content of the procedures has been modified by adding related problems and proposed mitigation activities (Table 4). The ultimate goal of these outputs is, finally, to provide formal and straightforward measures that can help SMEs implement BPM.

\section{Acknowledgments}

This work was supported by the Slovak Research and Development Agency under the contract No. SK-AT-2017-0003 and the Ministry of Education of the Slovak Republic and Slovak Academy of Sciences under the research project No. VEGA 1/0462/20 "Assessment changes in the qualitative structure of international economic relations under the influence of Industry 4.0 with implications for the EU and Slovak economic policies".

\section{References}

1. Ariyachandra, T. R., \& Frolick, M. N. (2008). Critical success factors in business performance management - Striving for success. Information systems management, 25 (2), 113-120. https://doi. org/10.1080/10580530801941504

2. Assarlind, M., Eroksson, H., Gremyr, I., \& Jakobsson, T. (2013). Adopting New Ways of Working in SMEs: Findings from Interventions in twelve European Companies. Total Quality Management \& Business Excellence, 24 (7-8), 945-958. https://doi.org/10.1080/14783363.2013.7 91108

3. Ates, A., Garengo, P., Cocca, P., \& Bititci, U. (2013). The development of SME managerial practice for effective performance management. Journal of Small Business and Enterprise Development, 20 (1), 28-54. https://doi.org/10.1108/1462600131129 8402

4. Belas, J., Dvorský, J., Strnad, Z., Valášková, K., \& Cera, G. (2019). Improvement of the quality of business environment model: Case of the SME segment. Inzinerine Ekonomika-Engineering Economics, 30 (5), 601-611. https://doi.org/10.5755/j01. ee.30.5.24490

5. Bianchi, C., Cosenz, F., \& Marinković, M. (2015). Designing dynamic performance management systems to foster SME competitiveness according to a sustainable development perspective: empirical evidence from a case study. International Journal of Business Performance Management, 16 (1), 84-108. https://doi.org/10.1504/IJBPM.2015.066042

6. Bititci, U., Garengo, P., Dörfler, V., \& Nudurupati, S. (2011). Performance measurement: challenges for tomorrow. International journal of management reviews, 14 (3), 305-327. https://doi. org/10.1111/j.1468-2370.2011.00318.x

7. Buganova, K., \& Simickova, J. (2019). Increasing the competitiveness of enterprises through implementation of risk management in the context of Industry 4.0 concept. In Kordos, M. (Ed.) Vplyv Industry 4.0 na tvorbu pracovných miest, 79-86. Trenčianske Teplice (Slovakia): Alexander Dubček University.

8. Campos, J., Sharma, P., Jantunen, E., Baglee, D., \& Fumagalli, L. (2017). Business performance measurements in asset management with the support of big data technologies. Management Systems in Production Engineering, 25 (3), 143-149. https://doi.org/10.1515/mspe-2017-0021

9. Çera, G., Belas, J., Rozsa, Z., \& Cepel, M. (2019). Linking firm characteristics to perceived important social factors for entrepreneurial activity. Economics and Sociology, 12 (4), 101-115. https://doi.org/10.14254/2071-789X.2019/12-4/6 
10. Davenport, T. H., Harris, J. G., \& Morison, R. (2010). Analytics at work: Smarter decisions, better results. Boston, Massachusetts: Harvard Business Press.

11. Dobrovic, J., Lambovska, M., Gallo, P., \& Timkova, V. (2018). Non-financial indicators and their importance in small and medium-sized enterprises. Journal of Competitiveness, 10 (2), 41. https://doi.org/10.7441/joc.2018.02.03

12. Ferreira, A., \& Otley, D. (2009). The design and use of performance management systems: An extended framework for analysis. Management Accounting Research, 20 (4), 263-282. https://doi. $\operatorname{org} / 10.1016 /$ j.mar.2009.07.003

13. Frolick, M. N., \& Ariyachandra, T. R. (2006). Business performance management: One truth. IS Management, 23 (1), 41-48. https://doi.org/10.1201/1078.10580530/45769.23.1.20061201/91 771.5

14. Glaister, K. W., Dincer, O., Tatoglu, E., Demirbag, M., \& Zaim, S. (2008). A causal analysis of formal strategic planning and firm performance. Management Decision, 46 (3), 365-391. https:// doi.org/10.1108/00251740810863843

15. Haseeb, M., Hussain, H. I., Kot, S., Androniceanu, A., \& Jermsittiparsert, K. (2019). Role of Social and Technological Challenges in Achieving a Sustainable Competitive Advantage and Sustainable Business Performance. Sustainability, 11 (14), 3811. https://doi.org/10.3390/ su11143811

16. Hernaus, T., Pejic Bach, M., \& Bosilj Vuksic, V. (2011). Influence of strategic approach to BPM on financial and non-financial performance. Baltic Journal of Management, 7 (4), 376-396. https://doi.org/10.1108/17465261211272148.

17. Heinicke, A. (2018). Performance measurement systems in small and medium-sized enterprises and family firms: a systematic literature review. Journal of Management Control, 28 (4), 457-502. https://doi.org/10.1007/s00187-017-0254-9

18. Jamil, C. M., \& Mohamed, R. (2011). Performance measurement system (PMS) in small and medium enterprises (SMEs): A practical modified framework. World Journal of Social Sciences, 1 (3), 20-212. https://pdfs.semanticscholar.org/d4d4/b5181d3c7498419e416acdc61497cace7d47. pdf

19. Kim, S. D., \& Jeon, I. O. (2016). Effects of Global Capabilities of Small and Medium Businesses on Their Competitive Advantage and Business Management Performances. International Journal of Fuгzy Logic and Intelligent Systems, 16 (1), 52-58. http://dx.doi.org/10.5391/ IJFIS.2016.16.1.52

20. Ključnikov, A., Mura, L., \& Sklenár, D. (2019). Information security management in SMEs: factors of success. Entrepreneurship and Sustainability Issues, 6 (4), 2081-2094. https://doi. org/10.9770/jesi.2019.6.4(37)

21. Klučka, J., \& Kelíšek A. (2018). Performance management - discussion to key performance, In Mihalčová et al. (Eds.) Production Management and Business Development. 121-124, London (United Kingdom): CRC Press, Taylor and Francis Group.

22. Korauš, A., Kaščáková, Z., \& Felcan, M. (2020). The impact of ability-enhancing HRM practices on perceived individual performance in IT industry in Slovakia. Central European Journal of Labour Law and Personnel Management, 3 (1), 34-46. https://doi.org/10.33382/ cejllpm.2020.04.03 
23. Kordos, M., \& Ivanova, E. (2017). The innovation union within the Slovak business environment. In P. Limpaphayom; G. Huang (Ed.), Proceedings of the Second International Conference on Economic and Business Management (FEBM 2017), Book Series: AEBMRAdvances in Economics Business and Management Research, 33, 391-396. Shanghai (Peoples Rep. of China).

24. Mura, L., Marchevska, M., \& Dubravska, M. (2018). Slovak Retail Business Across Panel Regression Model. Marketing and Management of Innovations, 4, 203-211. http://doi.org/10.21272/ mmi.2018.4-18

25. Okręglicka, M., Mynarzova, M., \& Kana, R. (2015). Business process maturity in small and medium-sized enterprises. Polish Journal of Management Studies, 12 (1), 121-131.

26. Pavelková, D., Homolka, L., Knápková, A., Kolman, K., \& Pham, H. (2018). EVA and Key Performance Indicators: The Case of Automotive Sector in Pre-Crisis, Crisis and Post-Crisis Periods. Economics and Sociology, 11 (3), 78-95. https://doi.org/10.14254/2071-789X.2018/11-3/5

27. Pejić Bach, M., Bosilj Vukšić, V., Suša Vugec, D., \& Stjepić, A. M. (2019). BPM and BI in SMEs: The role of BPM/BI alignment in organizational performance. International Journal of Engineering Business Management, 11, 1-16. https://doi.org/10.1177/1847979019874182

28. Pekkola, S., Saunila, M., \& Rantanen, H. (2016). Performance measurement system implementation in a turbulent operating environment. International Journal of Productivity and Performance Management, 65 (7), 947-958. https://doi.org/10.1108/IJPPM-01-2015-0018

29. Raffoni, A., Visani, F., Bartolini, M., \& Silvi, R. (2018). Business performance analytics: exploring the potential for performance management systems. Production Planning \& Control, 29 (1), 51-67. https://doi.org/10.1080/09537287.2017.1381887

30. Rajnoha, R., Lorincová, S., \& Bego, M. (2015). Strategic business performance management system in wood processing industry in Slovakia. Drvna industrija: Znanstveni časopis za pitanja drune tehnologije, 66 (2), 137-146. https://doi.org/10.5552/drind.2015.1504

31. Seotlela, R. P. J., \& Miruka, O. (2014). Implementation challenges of performance management system in the South African mining industry. Mediterranean Journal of Social Sciences, 5 (7), 177. https://doi.org/10.5901/mjss.2014.v5n7p177

32. Stefan, V., Duica, M., Coman, M., \& Radu, V. (2010). Enterprise performance management with business intelligence solution. In LA., Zadeh et al. (Eds.), Book series Recent Advances in Computer Engineering: 4th WSEAS International Conference on Business Administration (ICBA'10). 244-255 Cambridge, England: University Cambridge.

33. Strelcová,S., \& Janasová D. (2018) Hodnotenie výkonnosti podniku. 23. Medzinárodná vedecká konferencie, Riešenie krízových situácií v špecifickom prostredí. 338-345, Žilina (Slovakia): University of Žilina.

34. Taticchi, P., Cagnazzo, L., Santantonio, M., \& Tonelli, F. (2010). A framework for performance measurement and management based on axiomatic design and analytical hierarchy process. In Business Performance Measurement and Management, 229-240. Berlin, Heidelberg: Springer.

35. Tuček, D. (2015). The Main Reasons for Implementing BPM in Czech Companies. Journal of Competitiveness, 7 (3), 126-142. https://doi.org/10.7441/joc. 2015.03.09 
36. Weber, J., Bramsemann, U., Heineke, C., \& Hirsch, B. (2017). Wertorientierte Unternehmenssteuerung: Konzepte, Implementierung, Praxis-Elemente, Wiesbaden: Springer Verlag.

37. Whitford, C. M., \& Coetsee, W. J. (2006). A model of the underlying philosophy and criteria for effective implementation of performance management. $S$ A Journal of Human Resource Management, 4 (1), 63-73.

\section{Contact information}

Prof. (FH) Rudolf Gruenbichler, $M A$

Graz University of Technology | UAS CAMPUS 02

Faculty of Mechanical Engineering and Economic Sciences, Institute of Business Economics and Industrial

Sociology, Department of Financial and Management Accounting

Austria

E-mail:rudolf.gruenbichler@tugraz:at

ORCID:0000-0002-5872-5771

Assoc. prof. Ing. Jozef Klucka, Ph.D.

University of Zilina

Faculty of Security Engineering

Department of Crisis Management

Slovakia

E-mail:jozef.Klucka@fbi.uniza.sk

ORCID: 0000-0002-0994-6439

Ing. Katarina Haviernikova, Ph.D.

Alexander Dubček University of Trencín

Faculty of Social and Economic Relations

Department of Economy and Economics

Slovakia

E-mail:katarina.haviernikova@tnuni.sk

ORCID: 0000-0002-9019-8684

Assoc. prof. Ing. Stanislava Strelcova, Ph.D.

University of Žilina

Faculty of Security Engineering

Department of Crisis Management

Slovakia

E-mail:stanislava.strelcova@fbi.uniza.sk.

ORCID: 0000-0002-4497-4013 


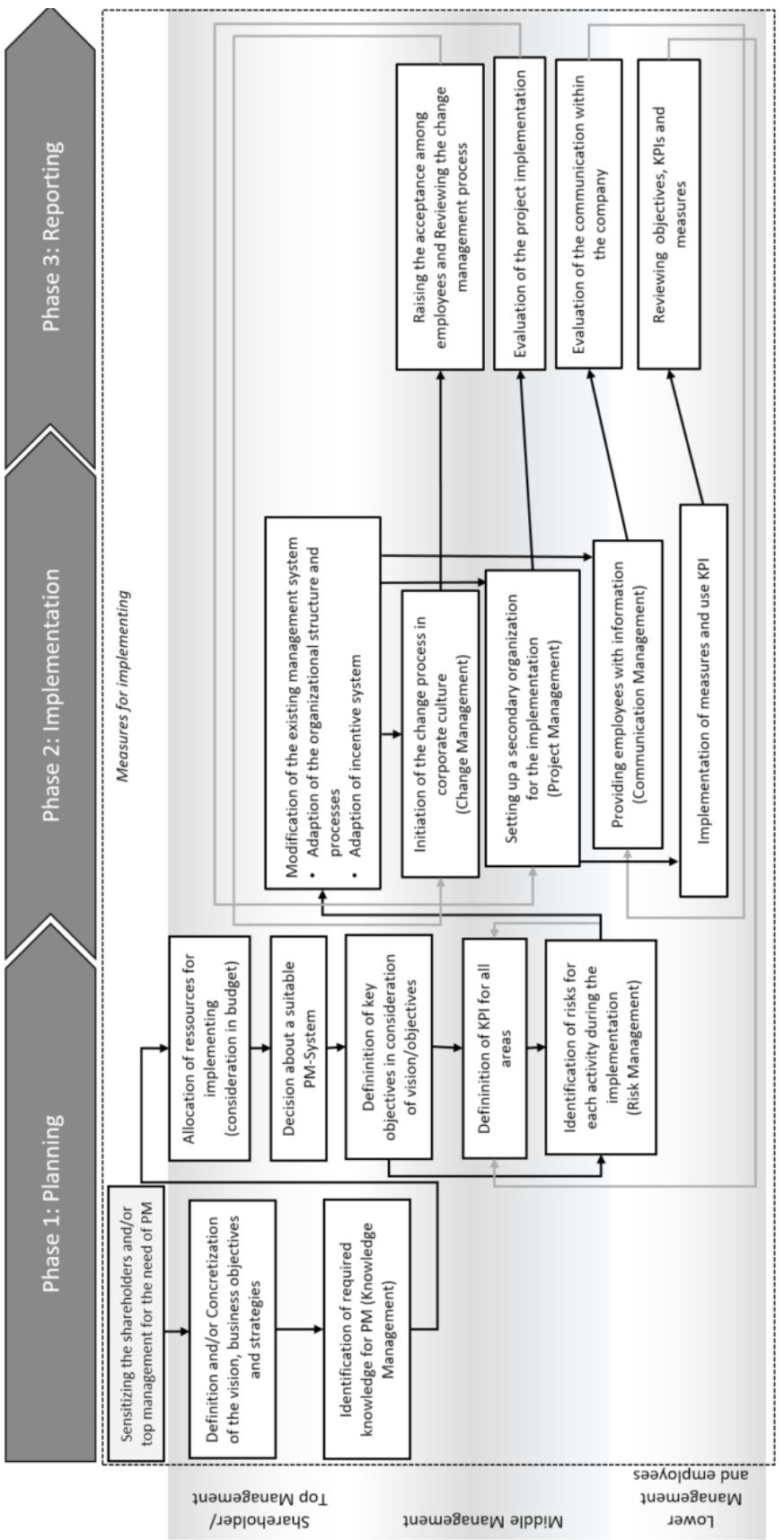

ssəวoıd u! ə|q!suodsəy

Fig. 1 - Integrated three-phase-framework for the implementation of BPM. Source: own research 